\title{
THE RIGHT OF ACCESS TO NON-STATE DISPUTE RESOLUTION IN THE LEGAL ORDER OF LARGER EUROPE: A YARDSTICK TO HARMONISE APPROACHES TO STATE AND NON-STATE DISPUTE SETTLEMENT IN UKRAINE
}

The Ukrainian legal thought has traditionally regarded the right of access to justice as a right of access to the State court, or to State managed or controlled procedures for dispute settlement. One of the main reasons for that was that the non-state, or uncontrolled by the State dispute settlement was not formally permitted, prohibition being imposed by the Soviet system and even to a certain extent during the period of domination on parts of the territory of the modern Ukraine, of the various externally imposed requirements of various legal systems in force at the material time. Non-state dispute settlement in its traditional forms, mainly based on the custom, was also left outside the attention in the pre-Soviet times and could not find its dignified place between accessible schemes and instruments for dispute settlement. Moreover, the understanding that justice delivery for the parties to the dispute should remain within State monopoly, became commonly accepted as from 1996. The adoption of the Constitution of Ukraine to a certain extent perverted approach to settlement of conflicts, focusing on the main role for the State courts, to these ends. In particular, the courts are having "direct jurisdiction" over any dispute, this led to perception of pre-trial settlements as unnecessary, even as regards those that remained in force, notably, the commissions on labour disputes that were recognized in the case-law of the European Court as equating in legal force to binding and enforceable legal instruments. Thus, the traditional historical approach to seeing judicial examination of disputes as an exceptional step in dispute settlement, in the absence of agreement or settlement by the parties, notably through mediation, arbitration or conciliation, various forms of third party involvement, steadily disappeared. However, alternative examination of disputes is returning back to its original standing. It is gaining its place in the discussions on the judicial reform and reform of the system for settlement of disputes. This reform is far from being finalised and possibly has not even started in practice. The new approach to settlement of disputes, aimed at breaking the principle of State monopoly on examination of disputes and seeing State dispute settlement by court as an exception, is still not firmly entrenched into the mentality of lawyers, public servants, judges, law enforcement employees and politicians in Ukraine. Thus, the article suggests and points out to importance of taking into account with these changes of a wider European perspective. Such a perspective should relate not only to theoretical and practical advantages of the non-state dispute settlement, but also provides that the privatisation of the dispute settlement procedures and breaking the state monopoly on it, is a part of wider international obligations, also being a part of the supranational legal order of the European Union. This obligation of Ukraine is also seen as part of the requirements stemming from the Council of Europe law. Both the EU law and the Council of Europe provide for extensive soft law recommendations, legal principles, which are formed by the case-law of the European Court of Human Rights. Such an approach provides that alternative means of dispute settlement, including arbitration, do not run contrary to the principles of human rights with regard to fair judicial proceedings. On the contrary, they could be seen as a highly relevant actual means of dispute settlement for any modern European society, built on the principles of respect to rule of law and human rights.

Keywords: alternative dispute resolution methods, access to justice, right to a fair trial, human rights, rule of law, pre-trial settlements, examination of conflicts, mediation.

\footnotetext{
${ }^{1}$ All views presented in this publication are personal and the authors don't necessarily have a single common view on the subject-matter, even though their views are fundamentally similar. The views of the authors don't represent any official position of the institutions where the authors work or exercise their duties. The elements of academic discussion presented in the present publication were presented at several academic events and the article is based on the participation of authors in these events and discussions on the alternative dispute resolution methods, both in Ukraine and in several European countries. Mr Vasyl Marmazov, PhD, is a professor of the Kyiv University of Law at the National Academy of Sciences of Ukraine, international arbitrator; Mr Pavlo Pushkar, PhD, is a doctoral candidate of Max Planck Institute Luxembourg for International, European and Regulatory Procedural Law, Head of division, Department for the Execution of Judgments of the European Court of Human Rights, Council of Europe.
}

(C) Vasyl Marmazov, Pavlo Pushkar, 2021 


\section{Introduction}

Arbitration as an alternative private dispute settlement tool and the judicial settlement of disputes have always been seen as two opposites in the theory and practice of law. On the one hand, arbitration is an expression of a free will of the parties as to the procedural and substantive rules they have agreed on to form the basis for settlement of their disputes. On the other hand, offering no alternatives as to settlement within strict margins of the applicable law, formalised by substantive and procedural law, state-controlled judicial resolution of a dispute results in coercion enforced by the state against the losing party, acting in the interests of justice, but also the winner. Both dispute settlement paths have similarities and differences. Both are legitimate and widely recognised dispute resolution methods. They do interact, notably in situations when arbitration is supported by state action in the constitution of a tribunal, collection of evidence, enforcement of interim measures, etc. They also have a tendency of looking at a dispute from different angles. In particular, arbitration can be prescribed by law or by contractual relations without any alternative of choice for the party and thus can be perceived as non-voluntary. In such an instance it is de facto imposed by coercion, through a state-imposed formally binding legal framework, and has legal elements similar to state-based dispute settlement. In addition to the above, both systems refer to parallel or even analogous substantive and procedural legal principles, which are based on the general principles of law, "recognised by civilised nations". Among these are ensuring access to justice, respecting independence and impartiality, conforming to principles of fairness and equity, adversariness in the proceedings, as well as recognising binding nature of outcomes achieved by the court judgments or arbitration awards and in ensuring unequivocal compliance with them. Both systems of dispute settlement interact through human rights law notably through assessment of compliance with the right to a fair hearing under Article 6 of the European Convention on Human Rights (hereafter Article 6-1). Thus, fair hearing guarantee serves as a common denominator for evaluating whether the dispute settlement had been fair. The task of this publication is to draw comparison between the two systems, based on such a common approach and to reach conclusions as to the areas of their interaction and mutual influence on dispute resolution.

This publication will explore several interlinked topics. Firstly, it will deal with the issue of the existence of the single European legal space where the arbitration and the right to a fair trial interact and complement one another. Second, it will describe specific right to fair hearing requirements applicable to review of arbitration proceedings. Third, it would describe the requirements of independence and impartiality as applicable to arbitration and the respective due process requirements. Fourth, it will provide for a restatement of the case-law in the leading Mutu and Pechstein case. Finally, conclusions would be made as to the importance of guidance from the point of view of a wider European view on mutual complementarity of various dispute settlement methods and judicial settlement of disputes. Such perspective addresses not only the philosophy and practical benefits of non-state dispute settlement, including efficiency, but also suggests that the system of private dispute settlement is an international obligation in the European Union supranational legal order. It also has its unique place in the legal order of the Council of Europe. Both systems have an extensive set of ideas based on state practice, soft law recommendations and legal principles arising from the case-law of the European Court of Human Rights. Such an approach suggests that alternative dispute resolution methods, notably arbitration, do not contradict human rights principles of fair administration of justice. Quite on the contrary, they appear to be a useful conflict resolution tool for any modern European legal system based on the principles of respect to the rule of law.

\section{Single European legal space on interaction between arbitration and the right to a fair trial?}

The return to the process of EU accession to the European Convention of Human Rights, which has been reinitiated fairly recently, underlines the need to ensure coherent coexistence of rules of the EU legal order and a larger Council of Europe legal order vis-à-vis protection of human rights. The European Convention of Human Rights, the Strasbourg Court's case-law and the state practices on implementation of the Convention are seen as constituent parts of the constitutional and legal order of the European states. This idea is deeply entrenched into the ideology of the EU Charter of Fundamental Rights, which confirms that the Charter shall be interpreted with reference to the case-law of the Strasbourg Court. It is reflected in both Articles 52 and 54 of the Charter. The principles pertinent to access to justice that arises from the Convention, under the right to fair hearing provisions, are by no means different from the ideas of the EU Charter of Fundamental Rights and the 
approach to these principles in the EU legal order. This approach is confirmed in the case-law of the European Court of Justice, which is in many ways parallel to jurisprudence of the Strasbourg Court. ${ }^{2}$ It is based on Article 6-1, i.e. the right to a fair trial or right to a fair hearing (hereafter - $\mathrm{RFH}$ ) and a private party's possibility to waive that right.

The Strasbourg Court very clearly underlined in the case of Regent Company v. Ukraine that the RFH requirement "does not preclude the setting up of arbitration tribunals in order to settle disputes between private entities". The Strasbourg Courts stated that the word "tribunal" ... is not necessarily to be understood as signifying a court of law of the classic kind, integrated within the standard judicial machinery of the country." The European Court recognised that the International Arbitration Tribunal at the Chamber of Commerce and Industry of Ukraine (ICAC or more commonly known as "MKAS", on the basis of the Ukrainian abbreviation) was a tribunal established by law, with special jurisdiction to deal with "commercial disputes with a foreign element" and that its awards are treated as equivalent to an enforceable court judgment. ${ }^{3}$

Furthermore, according to the most recent discussions by the President of the European Court of Human Rights, Professor Robert Spano, there is nothing to suggest that voluntary recourse to arbitration is intrinsically antagonistic to due process requirements. ${ }^{4}$ In particular, case-law clearly recognizes distinction between voluntary and compulsory arbitration, even though the Strasbourg Court's case-law evolved in its analysis of these forms of arbitration. The Strasbourg Court's judgments in the case of Ali Riza v. Turkey is a clear example of the European jurisdictional power to verify whether compulsory consent to arbitration agreement constituted a violation of Article 6-1. A breach of the Convention in this case had been based on the structural imbalance between athletes and governing bodies, the lack of independence of the arbitral body, an insufficient mechanism to challenge arbitrators and the inability to set aside the award. The requirements of independence and impartiality of an arbitral tribunal are therefore stricter in compulsory arbitration. On the other

2 Handbook on European law relating to access to justice. European Union Agency for Fundamental Rights and Council of Europe, 2016, 23.

See Regent Company v. Ukraine, judgment of 3 April 2008, $\S 54$, http://hudoc.echr.coe.int/eng?i=001-85681.

4 Amelia Kelly, "Human Rights and Arbitration: A discussion between the President of the European Court of Human Rights and Neil Kaplan," Kluwer Arbitration Blog, November 30, 2020, http:// arbitrationblog.kluwerarbitration.com/2020/11/30/ human-rights-and-arbitration-a-discussion-between-the-presidentof-the-european-court-of-human-rights-and-neil-kaplan/ hand, the party autonomy and a possibility of waiver of right to a fair hearing are more relaxed in cases of voluntary arbitration. The reasoning behind this is related to the nature of arbitration and in recognizing arbitration as a private method of dispute resolution, which validates the unilateral nature of consent in compulsory arbitration. Agreement to arbitrate requires a waiver of Article 6-1, however, this does not equate to a full waiver of a right to due process. Arbitration could also be reviewed for compliance with requirements of reasonable length of proceedings, from the point of view of efficiency in administration of justice.

This is especially true in matters of consumer disputes in the EU. ${ }^{5}$ Alternative dispute resolution procedures, such as arbitration, out-of-court settlement mechanisms that help consumers and traders solve conflicts fast. ${ }^{6}$ For instance, in relation to arbitration as an alternative dispute resolution method, the EU countries must ensure that the arbitration tribunals meet binding quality requirements, guaranteeing that they operate in an effective, fair, independent and transparent way. This is done by designating competent authorities, which have national oversight over ADR entities and ensure their compliance with the quality requirements. Moreover, traders who use ADR must inform consumers about ADR on their websites as well as in their general terms and conditions. This directive applies to all market sectors, with the exception of health and higher education. In addition to the above, member States shall ensure that the natural persons in charge of ADR possess the necessary expertise and are independent and impartial. This shall be guaranteed by ensuring that such persons shall be competent in ADR matters, be independent and impartial, provide transparent information about their services, length of proceedings, costs, enforceability of the award, etc. The EU directives, as supranational legal instruments

5 Recommendation 98/257/EC, Decision 20/2004/EC and Council Resolution 2000/C 155/01 of 25 May 2000 lay down the principles to be followed in ADR proceedings, aimed at guaranteeing the individual consumer cheaper and faster remedies. Directive 2009/22/EC on injunctions for the protection of consumers' interests harmonises existing EU and national law and, in order to protect the collective interests of consumers, introduces the 'action for injunctions', which can be opened at the competent national court level against infringements by commercial operators from other countries.

6 Directive 2013/11/EU of 21 May 2013 on alternative dispute resolution for consumer disputes gives consumers the possibility of turning to quality alternative dispute resolution entities for all kinds of contractual disputes with businesses over an online or offline, domestic or cross-border purchase. Regulation (EU) No 524/2013 of 21 May 2013 on online dispute resolution enables EU consumers and traders to settle online disputes concerning domestic and crossborder purchases, through an EU-wide dispute resolution platform to which ADR bodies have been able to sign up since February 2016, https://www.europarl.europa.eu/factsheets/en/sheet/47/ consumer-protection-measures 
with direct binding force, provide for national transposition measures concerning Directive 2013/11/EU of the European Parliament and of the Council of 21 May 2013 on alternative dispute resolution for consumer disputes and amending Regulation (EC) No 2006/2004 and Directive 2009/22/EC (Directive on consumer ADR). ${ }^{7}$

\section{Specific RFH requirements in relation to review of arbitration proceedings}

From the point of view of human rights law and the principles of rule of law enshrined in $\mathrm{RFH}$, arbitration is seen as an instance of free and voluntary waiver of the right to a fair trial. In signing the arbitration clause, the applicant waives the right to bring the disputes before an ordinary court, such a waiver frequently encountered and recognized as lawful and permissible in the Contracting States' domestic legal systems. The arbitration, according to the constant case-law of the Court, has undeniable advantages for the individual concerned as well as for the administration of justice, and does not in principle offend against the Convention. ${ }^{8}$ In particular, the right of access to court may be renounced in civil matters in favour of arbitration, provided this is done freely, without duress and constraint. ${ }^{9}$ Arguably, arbitration courts should "follow up" and comply with four components of the right to a fair trial (a) the right to a fair hearing as such, (b) the right to an independent and impartial tribunal established by law, (c) the right to a public hearing and the public pronouncement of judgments, and (d) the right to a fair trial within a reasonable time. ${ }^{10}$

Firstly, the RFH standards provide that, with respect to the waiver, there is nothing to prevent an applicant from waiving certain rights, provided that such a waiver is, as in the instant case, lawful and unequivocal and without constraints. ${ }^{11}$ Moreover, a waiver, in order to be valid, has to be unequivocal and requires certain minimum guarantees commensurate with its importance. ${ }^{12}$ Furthermore,

\footnotetext{
${ }^{7} \mathrm{https}$ ://eur-lex.europa.eu/legal-content/EN/NIM/?uri=celex 32013L0011

8 See the Deweer v. Belgium, judgment of 27 February 1980 Series A no. 35, p. 25, § 49.

9 See Pastore v. Italy (dec.), no. 46483/99, 25 May 1999

${ }_{10}$ Jernej Letnar Cernic, "Emerging Fair Trial Guarantees Before the Court of Arbitration for Sport," European Society of Interna tional Law, 10 $0^{\text {th }}$ Anniversary Conference, Vienna, 4-6 September 2014, Conference Paper No. 9/2014 (September 4, 2014), http:// dx.doi.org/10.2139/ssrn.2546183

${ }^{11}$ See Pfeifer and Plankl v. Austria, judgment of 25 February 1992, Series A no. 227, p. 16-17, § 37; Transado-Transportes Fluviais do Sado, S.A. v. Portugal (dec.), no. 35943/02, 16 December 2003; Lundgren v. Sweden, decision of the Commission of 17 May 1995, no. 22506/93.

${ }^{12}$ See Pfeifer and Plankl v. Austria, judgment of 25 February 1992, Series A no. 227, p. $16, \S 37$.
}

there is no doubt that a voluntary waiver of court proceedings in favour of arbitration is in principle acceptable from the point of view of the RFH. Even so, such a waiver should not necessarily be considered to amount to a waiver of all the rights under the RFH. ${ }^{13}$

Secondly, an unequivocal waiver of Convention rights is valid only insofar as such waiver is "permissible". Waiver may be permissible with regard to certain rights, but not with regard to certain others. A distinction may have to be made even between different rights guaranteed by the RFH. Thus, in the light of the case-law it is clear that the right to a public hearing can be validly waived even in court proceedings. ${ }^{14}$ The same applies, a fortiori, to arbitration proceedings, one of the very purposes of which is often to avoid publicity. On the other hand, the question whether the fundamental right to an impartial judge can be waived at all, was left open in the Pfeifer and Plankl v. Austria case, as in any case in the circumstances of that case there was no unequivocal waiver. In deciding on this element of the case the Court limited itself to the particular circumstances of that case, which concerned arbitral proceedings and took into account the applicable legislative framework for arbitration proceedings and the control exercised by the domestic courts within that framework of domestic procedural safeguards. ${ }^{15}$

Thirdly, the Court's case-law underlines that a waiver can be explicit or tacit, in the latter case for example by refraining from submitting or maintaining a request for a hearing. ${ }^{16}$

Furthermore, with respect to possibility to review waiver, the Court's view is that the Contracting States enjoy considerable discretion in regulating the question on which grounds an arbitral award should be quashed, since the quashing of an already rendered award would often mean that a long and costly arbitral procedure will become useless and that considerable work and expense must be invested in new proceedings. ${ }^{17}$ Somewhat similar considerations apply to review of the award, any judgment of the court of arbitration, before it is enforced, needs to be recognized by the domestic court. The requirement

\footnotetext{
${ }^{3}$ Cf. Bramelid and Malmström v. Sweden (dec.), nos. 8588/79 and 8589/79, 12 December 1983, D.R. 38, p. 38.

14 See, Håkansson and Sturesson v. Sweden, judgment of 21 February 1990, Series A no. 171, pp. 20-21, §§ 66-67.

${ }^{15} \mathrm{Cf}$. Nordström-Janzon and Nordström-Lehtinen $v$. the Netherlands (dec.), 27 November 1996, D.R. 87-A, pp. 115-116; Suovaniemi and Others v. Finland (dec.), no. 31737/96, 23 February 1999.

16 See, among other authorities, Håkansson and Sturesson $y$ Sweden, 21 February 1990, § 66, Series A no. 171-A; SchulerZgraggen v. Switzerland, 24 June 1993, § 58, Series A no. 263); Liuksila v. Finland (dec.), no. 13224/05, 16 June 2009.

${ }_{17}$ See Suovaniemi and Others v. Finland (dec.), no. 31737/96, 23 February 1999.
} 
of recognition is a further institution by which the courts exercise control over the jurisprudence of the courts of arbitration, whereas the arbitration court's judgment can be quashed, among other things, if in the proceedings before the court of arbitration the rules of fair trial were not respected. ${ }^{18}$ Also, the grounds on which arbitral awards may be challenged before national courts differ among the Contracting States. It cannot be required under the Convention that national courts must ensure that arbitral proceedings be reviewed from the point of view of their conformity with the RFH requirements. In some respects, in particular as regards publicity, it is clear that arbitral proceedings are often not even intended to be in conformity with the RFH, and the arbitration agreement entails a renunciation of the full application of that provision.

Thus, an arbitral award does not necessarily have to be quashed because the parties have not enjoyed all the guarantees of RFH, but each Contracting State may in principle decide itself on which grounds an arbitral award should be quashed. ${ }^{19}$ Insofar as arbitration is based on agreements between the parties to the dispute, it is a mere natural and logical consequence of their right to regulate their mutual relations as they see fit. From a more general perspective, arbitration procedures can also be said to pursue the legitimate aim of encouraging non-judicial settlements, restoring status quo ante with respect to the conflictual situations and of relieving the courts of an excessive burden of cases. The examination of a dispute by arbitration, having no indications of any issues of public interest which would have made an arbitration inappropriate or unreasonable, appears acceptable for the Court. ${ }^{20}$

\section{Requirements of independence and impartiality of arbitrators and arbitration's due process requirements}

Analyzing two specific requirements in arbitration proceedings as to the independence and impartiality of the arbitration tribunal and due process proceedings before the arbitration court, one might see a lot of resemblance of these requirements with those under the RFH requirements as to independence and impartiality of a judge and overall fairness of the proceedings. It has been suggested that as the fair trial guarantee is of such a fundamental constitutional

\footnotetext{
18 See, mutatis mutandis, Zamet-Budowa Maszyn Spolka Akcyjna v. Poland (dec.), § 28, no. 1485/11, 25 August 2015.

19 See Nordstrom-Janzon and Nordstrom Lehtinen v. The Netherlands, Decision of the Commission's Second Chamber, no. 28101/95, 27 November 1996.

20 See Axelsson and Others v. Sweden (decision of the Commission), no. 11960/86, 13 July 1990.
}

importance for European states legal orders that it should be applied fully for settlement of cases by means of arbitration and as a matter of public policy considerations. They mention two grounds for that. Firstly, the State regulates arbitration and thus should be responsible for ensuring that guarantees stemming from public policy considerations are applied. Secondly, the drittwirkung effect or horizontal effect in application of the Convention, which is also encompassing general principles of law in the area of administration of justice and dispute settlement, is binding on relations between the private parties in the same domain.

It is difficult to fully agree with such an approach, especially for disputes of trivial contractual nature with economic elements only and without any elements of non-arbitrability or inherent public policy considerations, even though the moral grounds or even profound idealistic grounds for such suggestions are rather understandable. The whole point of arbitration is to allow a flexible solution for a dispute settlement involving the parties, with as less State interference and regulation as possible. Arbitration is not about establishing ultimate truth or determining who was right or wrong - it is about settling a dispute and resolving a conflict. It seems that the approach to arbitration suggested in the Convention recognizes validity of the party autonomy based on good faith, state's non-interference and underlines a liberal approach as to waiver of rights under arbitration agreements. It is difficult to conceive that the caselaw of the Court, which can be seen as excessively intrusive, is aiming to impose such unreasonable constraints on essentially private law matters of how the disputes between the parties should be settled. Indeed, the Convention is an important legal instrument of the European constitutional order, however it is not a universally applicable legal regulator, nor does it encompass or prescribe rules for all and any kind of legal relations, including those in the area of dispute settlement.

The minimal standards of "fair trial" should be applied in the context of arbitration proceedings, on a case to case basis. They cannot be treated as similar requirements to cases settled by the State courts, with higher degree of legal reliability. In theory legitimacy is based on independence and impartiality and force of law, unless and most probably, as case-law says, the arbitration was compulsory under the law, had coercive effect, without a waiver of rights under the RFH guarantees. For instance, as mentioned above, the requirements of independence and impartiality of a judge are a lot stronger and are legally distinct from those as to "neutrality of the arbitrator". Arbitrator should have no interest in the outcome of the case, 
except possibly for ensuring his professional reputation and his desire to get another appointment. A judge has a special status within the domestic bureaucracy and special relations within the system of political power of the state. In this sense, more demanding requirements for arbitrators' independence and impartiality should not, in principle, be imposed through the Strasbourg case-law on the domestic legal systems, which should permit space for an efficient settlement of private law disputes, without involvement of the State, allowing parties more control over the means of such a settlement. For instance, the payment of arbitrator's fees or the parties' appointments should not be perceived as questioning the arbitrators' independence and impartiality from such a point of view.

The context of the judiciary is thus different. Its legitimacy is based on strongly entrenched in law, usually constitutional law, structural principles of independence and impartiality. Even though, this is probably the main reason why in a number of states private parties prefer to settle disputes outside the domestic judiciary and have opted for private arbitration, avoiding judicial examination in controversial situations of states experiencing systemic and structural problems identified in the judgments of the Strasbourg Court, such as instances of political or economic corruption or pressure from the executive and legislative branches of power. Thus, in such situations, in theory, the parties can arguably rely more on non-state dispute settlement and its equity and fairness as they cannot be entirely sure that the private disputes in which they are involved will be settled by an independent and impartial judge, who belongs to the domestic state controlled legal system.

As to due process requirements - they are mostly the same as in the case-law of the Court. The principles of equality of arms and adversariness of the proceedings being seen as core principles to, in principle, any arbitration, ad hoc or institutional. However, in voluntarily arbitrations, even in case where a party did not have a reasonable opportunity to present its case or to comment to the arguments of another party, but both parties agreed to such a procedure for settlement of a dispute beforehand (for instance simplified arbitration without hearing of a case, but with a mere expedited review of written submissions, with an award on the basis of "closest outcome" submission, as in the so-called "baseball arbitration"), it would not be for the Strasbourg Court to impose a different RFH standard. The suggested rules shall apply, shall stand and it would be for the domestic courts, in view of the public policy (ordre public) considerations, in the first place, to examine whether the waived right to a full trial had been interfered with or not. On the other hand, if an award would be set aside in such circumstances, it would be then for the domestic courts and eventually the Strasbourg Court, upon submission of one of the parties, to verify whether such a setting aside was compatible with a right to waive full fair hearing guarantees under the RFH guarantee.

Thus, the requirements of independence and impartiality $^{21}$ applied to the private settlement of disputes differ from those applied to the settlement of disputes involving a state judicial system. ${ }^{22}$ In the context of arbitration, the arbitrators are usually checked on their "partiality" 23 and "dependence" in relation to the parties. In brief, partiality arises where an arbitrator favours one of the parties, or where he is prejudiced in relation to the subject matter of the dispute; dependence may therefore arise from a relationship between an arbitrator and one of the parties. ${ }^{24}$ In arbitration, the guarantees of independence and impartiality are frequently replaced by a wider and more flexible guarantee of the arbitrator's "neutrality", which in arbitration proceedings emphasises on the arbitrator's 'taking a certain distance in relation to his legal, political and religious culture". ${ }^{25}$ Neutrality involves a subjective test of lack of actual or hidden bias or of having an impartial state of mind. ${ }^{26}$ It is to be assessed with reference to particular facts or objective circumstances, including the arbitrator's nationality. ${ }^{27}$ Applying this test, the sole arbitrator/chairman of the tribunal is "neutral" and presumed independent and impartial if his nationality is different from those of the parties. ${ }^{28}$

21 "Independence" is defined as freedom from control or influence exerted by others, whereas "impartiality" is an inclination to weigh both views and opinions equally, objectively. Impartiality refers to the absence of any bias with respect to a particular person or opinion. (Cambridge Advanced Learners' Dictionary, 2nd ed., 2004, or the Compact Oxford English Dictionary of Current English, 3rd ed., 2005).

${ }_{22}$ Chiara Giovannucci Orlandi, "Ethics for International Arbitrators," 67 UMKC L. Rev., 93-4.

${ }^{23}$ In some instances, the courts refer to the notion of "evident partiality", as for instance in the case of Morelite Construction Corporation v. New York City District Council Carpenters Benefit Funds, 748 F. 2 d 79.

24 Summary of Recent Changes to the Code of Ethics for Arbitrators in Commercial Disputes. American Arbitration Association, 2004; IBA Guidelines on Conflict of Interest in International Arbitration of 22 May 2004; David Branson, "IBA Rules of Ethics for International Arbitrators," published by International Business Lawyer 3, no. 1 (September 1987): 335.

25 Toby Landau, "Composition and Establishment of the Tribunal," Am Rev. Int'l Arb. 9 (1998): 45, 71-4.

26 "Independence is generally a function of prior or existing relationships that can be catalogued and verified, while impartiality is a state of mind," as cited in Christopher Koch's "Standards and Procedures for Disqualifying Arbitrators," Journal of International Arbitration 209, no. 4 (2003): 331-32.

27 Fouchard, Gaillard, Goldman, On International Commercial Arbitration, E. Gaillard and J. Savage, eds. (Kluwer Law International, 1999), 569-70.

28 M. Scott Donahey, "The Independence and Neutrality of Arbitrators," Journal of International Arbitration 9, no. 4 (1992): $31-2$. 
To sum up, when examining cases involving arbitration matters, one should always look into the context of these proceedings and take into account the specificity of arbitration matters, their difference from the "normal" adjudication by the domestic courts, looking not only at the waiver of a right as such, but also into the content of the requirements of independence and impartiality in a given case, in a larger context of due process in arbitration. This would imply that minimum standards of fairness, equity or due process (we use these terms interchangeably or synonymously) would still apply. In this sense the following restatement of the caselaw conclusions would be of interest:

- the RFH guarantee does not preclude the setting up of arbitration tribunals in order to settle disputes between private entities;

- the private parties have a right to agree voluntarily to keep out of the ordinary courts certain disputes which might arise in the course of execution of the contract between them and to waive (renounce) certain rights implicitly and explicitly enshrined by the RFH guarantee;

- the ordinary courts can reject requests for access, if there was an arbitration agreement;

- there is clear distinction between arbitration compulsory by law or even by nature of contractual relations leaving no right to opt out of arbitration agreement, which should offer all guarantees of the RFH and noncompulsory arbitration which should in principle comply with the requirements mentioned by the parties;

- in both types of arbitrations, the parties should be on equal footing in influencing composition of the arbitration tribunal, commenting mutual submissions and in the conduct of arbitration;

- the waiver of a right under the RFH and decision to be participate in arbitration proceedings must be voluntary and the Court must look into verifying this voluntariness, including its unequivocal nature;

- the domestic courts can exercise certain limited control over the conduct of arbitration proceedings and are responsible for that supervision;

- the supervision is focused on that there is no manifest illegality and arbitrariness in the arbitration proceedings;

- applicable legislative framework for arbitration and degree of control exercised by the domestic courts within this framework can also be reviewed;
- an arbitral award does not necessarily have to be quashed because the parties have not enjoyed all the guarantees of RFH, but each Contracting State may in principle decide itself on which grounds an arbitral award should be quashed;

- failure to enforce an arbitration award would constitute a breach of the RFH, similarly to non-compliance with the judgments of the state court, especially in situations concerning non-enforcement against state debtors.

\section{The restatement and coherent consolidation of the Court's case-law in the case of Mutu and Pechstein v. Ukraine}

From the point of view of correlation between out-of-court procedures and judicial examination, the case-law of the Court regards the arbitration procedure as a legitimate offer of "access to justice", allowing reasonable alternative means to effectively protect rights under the Convention. From this point of view, the limitations placed on the access to the courts are seen proportionate to the legitimate aims pursued, such limitations not impairing the right of access to court guaranteed by the RFH. ${ }^{29}$ In certain instances though, the Court's case-law denies the fact that the arbitration tribunal could be a "tribunal established by law", in the context of notably specific administrative procedures relating to pensions, possessing no necessary attributes of independence and impartiality. ${ }^{30}$

The approaches in the case-law above, have been summarily observed and reiterated in the cases of Mutu and Pechstein v. Switzerland and most recently reiterated in the judgment of the Court in the case of Riza v. Turkey ${ }^{31}$, referred to above:

..92. The Court reiterates that Article $6 \S 1$ of the Convention secures to everyone the right to have any claim relating to his civil rights and obligations brought before a court or tribunal. In this way the Article embodies the "right to a court", of which the right of access, that is the right to institute proceedings before courts in civil matters, constitutes one aspect only (see Lupeni Greek Catholic Parish and Others v. Romania [GC], no. 76943/11, § 84, 29 November 2016, and Golder v. the United Kingdom, 21 February 1975, § 36, Series A no. 18).

\footnotetext{
29 See, mutatis mutandis, Klausecker v. Germany (dec.), no. 415/07, 6 January 2015.

${ }^{30}$ See Süssmann and Stieler v. Germany, no. 20024/92, decision (partial) of the Commission's Plenary of 8 September 1993.

31 See Riza v. Turkey, nos. 30226/10, 5506/16 and Others, judgment of 28 January 2020, http://hudoc.echr.coe.int/ eng? $\mathrm{i}=001-200548$
} 
93. The right of access to a court, as secured by Article $6 \S 1$, is not absolute but may be subject to limitations; these are permitted by implication since the right of access by its very nature calls for regulation by the State. In laying down such regulation, the Contracting States enjoy a certain margin of appreciation. The final decision as to observance of the Convention's requirements rests with the Court, which must be persuaded that the limitations applied do not restrict the access left to the individual in such a way or to such an extent that the very essence of the right is impaired. Furthermore, a limitation will not be compatible with Article $6 \S 1$ if it does not pursue a legitimate aim and if there is not a reasonable relationship of proportionality between the means employed and the aim sought to be achieved (see Lupeni Greek Catholic Parish and Others, cited above, $\S 89$; Eiffage S.A. and Others v. Switzerland (dec.), no. 1742/05, 15 September 2009; Osman v. the United Kingdom, 28 October 1998, § 147, Reports of Judgments and Decisions 1998-VIII; and Waite and Kennedy v. Germany [GC], no. 26083/94, § 59, ECHR 1999-I).

94. This access to a court is not necessarily to be understood as access to a court of law of the classic kind, integrated within the standard judicial machinery of the country; thus, the "tribunal" may be a body set up to determine a limited number of specific issues, provided always that it offers the appropriate guarantees (see Lithgow and Others v. the United Kingdom, 8 July 1986, $\S 201$, Series A no. 102). Article 6 does not therefore preclude the establishment of arbitral tribunals in order to settle certain pecuniary disputes between individuals (see Suda v. Czech Republic, no. 1643/06, § 48, 28 October 2010). Arbitration clauses, which have undeniable advantages for the individual concerned as well as for the administration of justice, do not in principle offend against the Convention (see Tabbane v. Switzerland (dec.), no. 41069/12, § 25, 1 March 2016).

95. In addition, a distinction must be drawn between voluntary arbitration and compulsory arbitration. If arbitration is compulsory, in the sense of being required by law, the parties have no option but to refer their dispute to an arbitral tribunal, which must afford the safeguards secured by Article $6 \S 1$ of the Convention (see Suda, cited above, $\S 49$ ).

96. However, in the case of voluntary arbitration to which consent has been freely given, no real issue arises under Article 6. The parties to a dispute are free to take certain disagreements arising under a contract to a body other than an ordinary court of law. By signing an arbitration clause, the parties voluntarily waive certain rights secured by the Convention. Such a waiver is not incompatible with the Convention provided it is established in a free, lawful and unequivocal manner (see Eiffage S.A. and Others, cited above; Suda, cited above, $\S 48 ; R$. v. Switzerland, no. 10881/84, Commission decision of 4 March 1987, Decisions and Reports (DR) no. 51; Suovaniemi and Others, cited above; Transportes Fluviais do Sado S.A. v. Portugal (dec.), no. 35943/02, 16 December 2003; and Tabbane, cited above, $\S 27$ ). In addition, in the case of certain Convention rights, a waiver, in order to be effective for Convention purposes, requires minimum guarantees commensurate to its importance (see Pfeifer and Plankl v. Austria, 25 February 1992, § 37, Series A no. 227, and Tabbane, cited above, $\S 27)$...

As a follow up to the Mutu and Pechstein caselaw, the Court adopted an admissibility decision in the case of Tabbane $v$. Switzerland ${ }^{32}$, concerning waiver of right to appeal against arbitration award. The Court declared the application in that respect inadmissible for manifestly lacking foundations in its reasoning. In this case, the Swiss Federal Court refused to examine the arbitration award, considering that the parties had validly waived the right to appeal against any decision issued by the arbitration tribunal in accordance with section 192 of the Federal Law on Private International Law (hereafter - LPIL). In the Federal Court's view, the waiver was not in itself contrary to the RFH, given that section 192 of the LPIL required that the waiver be explicit and common to all the parties. The Federal Court further stated that the waiver of rights under the RFH guarantee could be declared void only in the absence of true consent and that, by the very nature of arbitration, it was difficult to see what important public interest might be infringed in the ordinary course of events by an advance waiver of a right to appeal. The Court, in examining the application from the point of view of compliance with the RFH requirements, on the part of access to a court, established that arbitration had not been imposed by the law, but had been the result of the parties' contractual freedom. The Court underlined that the applicant had, without constraint, expressly and freely waived the possibility of submitting potential disputes to the ordinary courts, which would have provided him with all the guarantees of the RFH. In the Strasbourg Court's view, the waiver had been unequivocal and had been attended by minimum safeguards, reflecting the importance of the waiver. Furthermore, the Court even analyzed the impugned legal provisions of the domestic law and ruled that they reflected a choice of legislative policy corresponding to a two-fold wish on the part of the Swiss legislature. The Court stated that, firstly, the aim of such legislation and institutions was to increase

\footnotetext{
${ }^{32}$ Information Note on the Court's case-law 194, March 2016; Tabbane v. Switzerland (dec.) - 41069/12, Decision 1.3.2016 [Section III], http://hudoc.echr.coe.int/eng?i=002-11120
} 
the attractiveness and effectiveness of international arbitration in Switzerland by avoiding situations in which arbitration awards were subject to review by both an appellate body and the judge responsible for its enforcement. In addition to that, the Court mentioned that, secondly, the aim had been to relieve the Federal Court of such cases. For the Strasbourg Court, such an approach to legal regulation did not appear disproportionate to the aim pursued. In short, from the Strasbourg Court's point of view, the restriction had pursued a legitimate aim, namely promoting Switzerland's position as a venue for international and domestic commercial arbitration, through flexible and rapid procedures, while respecting the parties' contractual freedom. Such an approach for the Court could not be regarded as disproportionate. Based on the above, the Court concluded thus that the very essence of the right of access to a court had not been impaired. ${ }^{33}$

More generally, the Court's case-law reconfirms undeniable advantages of arbitration, which actually improves general access to justice to all, via firstly reducing the workload of the courts and then offering an alternative dispute resolution avenue not based on coercion only, but rather based on the idea of consensual search for dispute resolution. In this sense many member states of the EU, and larger Europe composed of the Council of Europe member states, have adopted legislation to encourage the development of arbitration, among other dispute settlement means and, most recently, on-line arbitration to respond to COVID-19 pandemic.

\section{Concluding remarks}

Arbitration as an alternative dispute settlement tool and the judicial settlement of disputes have always been seen as two opposites - arbitration as an expression of a free will of the parties as to the procedural and substantive rules they have agreed on as a basis for settlement of their disputes and a statecontrolled judicial resolution of a dispute based on formally applicable law and procedure, largely based on coercion by the state. Both dispute settlement paths have similarities, sometimes even analogous substantive and procedural elements, and both have differences. The two systems of dispute resolution, state-binding and private-consensual, can interact. In certain instances, arbitration is prescribed by law or

${ }^{33}$ See above. Legal summary of the case produced by the Registry of the Court, with further references to the following cases concerning "arbitration issues": Eiffage S.A. and Others v. Switzerland (dec.) 1742/05, 15 September 2009; Osmo Suovaniemi and Others v. Finland (dec.), 31737/96, 23 February 1999; Transportes Fluviais do Sado S.A. v. Portugal (dec.), 35943/02, 16 December 2003; and Suda v. the Czech Republic, 1643/06, 28 October 2010, Information Note 134. by contractual relations without alternatives and thus is non-voluntary, being both de facto imposed by coercion, but still considered legally binding. There are parallel substantive and procedural principles in both systems, which are both based on the general principles of law, ideas of decentralised and non-state justice. Among these are ensuring access to justice, independent and impartial examination of disputes, fairness and equity as well as enforcement of outcomes achieved by the court judgments or the arbitration awards. Both systems of dispute settlement interact through human rights law, notably through assessment of compliance with the right to a fair trial under the RFH. In this respect, the Strasbourg Court has adopted a firm and consistent approach to the arbitration, stating that arbitration clauses, which present clear benefits for the administration of justice, do not in principle offend against the Convention and its requirements under the RFH.

In particular, the Court's case-law recognizes that in subscribing to an arbitration clause, the parties voluntarily renounce certain rights under the Convention. Such a renunciation - so far as it is legitimate and done in good faith - must be established in an unequivocal manner and attended by minimum safeguards corresponding to its importance. In a situation, where the arbitration clause is not called into question, where it has been voluntarily agreed to without equivocation and its application was attended by necessary safeguards, the arbitration proceedings do not raise any concerns under the Convention, as the party, once again, renounces certain guarantees provided for in RFH. Such a renouncement does not contradict principles of fairness enshrined in the Convention and should not be interfered with. As a result, the principles of fairness in arbitration are not necessarily those referred to in the provisions of the Convention, reconfirmed in the Court's case-law. These standards, as applicable to arbitration, equity and fairness, can be more narrow, serving contractual freedom stemming from agreement and the interests of the parties, but still being as a matter of principle concordant with the European Convention on Human Rights and the requirements of the RFH. In any case, one cannot agree more that more focused research is required on the topic of interrelations between alternative dispute resolution, arbitration and human rights. ${ }^{34}$ Different directions of thought and further research could be employed for the topic, including a comparative law method.

\footnotetext{
34 Lorna McGregor, "Alternative Dispute Resolution and Human Rights: Developing a Rights-Based Approach through the ECHR," European Journal of International Law 26, Issue 3 (August 2015): 607-34, https://doi.org/10.1093/ejil/chv039. Published on 5 November 2015
} 


\section{Bibliography}

\section{Academic literature}

Branson, David. "IBA Rules of Ethics for International Arbitrators." International Business Lawyer 3, no. 1 (September 1987): 335.

Cambridge Advanced Learners' Dictionary. 2nd ed. Cambridge University Press, 2004.

Compact Oxford English Dictionary of Current English. $3^{\text {rd }}$ ed. Oxford University Press, 2005.

Donahey, M. Scott. "The Independence and Neutrality of Arbitrators." Journal of International Arbitration 9, no. 4 (1992): 31-42.

Gaillard, Emmanuel and John Savage, eds. Fouchard Gaillard Goldman On International Commercial Arbitration. Kluwer Law International, 1999.

Kelly, Amelia. "Human Rights and Arbitration: A discussion between the President of the European Court of Human Rights and Neil Kaplan.” Kluwer Arbitration Blog. November 30, 2020 http://arbitrationblog.kluwerarbitration.com/2020/11/30/human-rights-and-arbitration-a-discussion-between-the-president-of-the-european-court-of-human-rights-and-neil-kaplan/

Koch, Christopher. "Standards and Procedures for Disqualifying Arbitrators." Journal of International Arbitration 20, no. 4 (2003): 325-353.

Landau, Toby. "Composition and Establishment of the Tribunal." Am Rev. Int'l Arb. 9 (1998): 45-106.

Letnar Cernic, Jernej. "Emerging Fair Trial Guarantees Before the Court of Arbitration for Sport." European Society of International Law, $10^{\text {th }}$ Anniversary Conference, Vienna, 4-6 September 2014, Conference Paper No. 9/2014. (September 4, 2014). http://dx.doi. org/10.2139/ssrn.2546183

McGregor, Lorna. "Alternative Dispute Resolution and Human Rights: Developing a Rights-Based Approach through the ECHR." European Journal of International Law 26, Issue 3 (August 2015): 607-34. https://doi.org/10.1093/ejil/chv039

Orlandi, Chiara Giovannucci. "Ethics for International Arbitrators." UMKC L. Rev. 67 (1998): 93.

\section{International legal instruments of relevance}

IBA Guidelines on Conflict of Interest in International Arbitration (Approved on 22 May 2004 by the Council of the International Bar Association, 2004).

Directive 2009/22/EC on injunctions for the protection of consumers' interests.

Directive 2013/11/EU of 21 May 2013 on alternative dispute resolution for consumer disputes. https://www.europarl.europa.eu/ factsheets/en/sheet/47/consumer-protection-measures

Handbook on European law relating to access to justice. European Union Agency for Fundamental Rights and Council of Europe. (2016).

Recommendation 98/257/EC, Decision 20/2004/EC and Council Resolution 2000/C 155/01 of 25 May 2000 lay down the principles to be followed in ADR proceedings, aimed at guaranteeing the individual consumer cheaper and faster remedies.

Regulation (EU) No 524/2013 of 21 May 2013 on online dispute resolution. https://eur-lex.europa.eu/legal-content/EN/NIM/?uri= celex:32013L0011

Summary of Recent Changes to the Code of Ethics for Arbitrators in Commercial Disputes. American Arbitration Association, 2004
III. Case-law of the European Court of Human Rights (available in the HUDOC database) and other relevant cases

Axelsson and Others v. Sweden (decision of the Commission), no. 11960/86, 13 July 1990 ;

Bramelid and Malmström v. Sweden (dec.), nos. 8588/79 and 8589/79, 12 December 1983, D.R. 38, p. 38;

Deweer v. Belgium, judgment of 27 February 1980, Series A no. 35, p. 25, § 49;

Eiffage S.A. and Others v. Switzerland (dec.), 1742/05, 15 September 2009;

Håkansson and Sturesson v. Sweden, judgment of 21 February 1990 , Series A no. 171, pp. 20-21, §§ 66-67;

Håkansson and Sturesson v. Sweden, 21 February 1990, § 66 , Series A no. 171-A;

Klausecker v. Germany (dec.), no. 415/07, 6 January 2015;

Liuksila v. Finland (dec.), no. 13224/05, 16 June 2009;

Lundgren v. Sweden, decision of the Commission of 17 May 1995, no. 22506/93;

Morelite Construction Corporation v. New York City District Council Carpenters Benefit Funds, 748 F. 2d 79;

Nordstrom-Janzon and Nordstrom Lehtinen v. The Netherlands, Decision of the Commission's Second Chamber, no. 28101/95, 27 November 1996;

Nordström-Janzon and Nordström-Lehtinen $v$. the Netherlands (dec.), 27 November 1996, D.R. 87-A, pp. 115-116;

Osmo Suovaniemi and Others v. Finland (dec.), 31737/96, 23 February 1999 ;

Pfeifer and Plankl v. Austria, judgment of 25 February 1992, Series A no. 227, p. 16-17, § 37;

Pastore v. Italy (dec.), no. 46483/99, 25 May 1999;

Regent Company v. Ukraine, judgment of 3 April 2008, § 54, http:// hudoc.echr.coe.int/eng? $\mathrm{i}=001-85681$;

Riza v. Turkey, nos. 30226/10, 5506/16 and Others, judgment of 28 January 2020, http://hudoc.echr.coe.int/eng?i=001-200548;

Schuler-Zgraggen v. Switzerland, 24 June 1993, § 58, Series A no. 263);

Suda v. the Czech Republic, no. 1643/06, 28 October 2010, Information Note 134;

Suovaniemi and Others v. Finland (dec.), no. 31737/96, 23 February 1999;

Süssmann and Stieler v. Germany, no. 20024/92, decision (partial) of the Commission's Plenary of 8 September 1993;

Tabbane v. Switzerland (dec.) - 41069/12, Decision 1.3.2016 [Section III], http://hudoc.echr.coe.int/eng?i=002-11120;

Transado-Transportes Fluviais do Sado, S.A. v. Portugal (dec.), no. 35943/02, 16 December 2003;

Zamet-Budowa Maszyn Spolka Akcyjna v. Poland (dec.), § 28, no. 1485/11, 25 August 2015. 
Мармазов В. С., Пушкар П. В.

\section{ПРАВО НА ДОСТУП ДО НЕДЕРЖАВНОГО ВРЕГУЛЮВАННЯ СПОРІВ У ЗАГАЛЬНОЕВРОПЕЙСЬКОМУ ПРАВОПОРЯДКУ: ВІДПРАВНА ТОЧКА ДЛЯ ГАРМОНІЗАЦЇ̈ ПІДХОДІВ ДО ДЕРЖАВНОГО ТА НЕДЕРЖАВНОГО ВРЕГУЛЮВАННЯ СПОРІВ В УКРАЇНІ}

В українській правовій думці право доступу до правосуддя традиційно розумілося лише як право доступу до державного суду або ж до державних чи контрольованих державою процедур урегулювання спорів. Однією з причин такого розуміння $\epsilon$ те, що недержавне або ж неконтрольоване державою врегулювання спору не дозволялося в радянські часи. Недержавне врегулювання спорів у його традиційних формах також залишалося поза увагою в дорадянські часи і не знаходило свого місця серед доступних схем та інструментів урегулювання спорів. Більше того, розуміння того, що правосуддя для сторін спору має залишатися тільки в державній монополії, набуло поширення з 1996 року. Прийняття Конституції України дещо викривило підхід до врегулювання конфліктів, відводячи головну роль державним судам. Зокрема, суди мають безпосередню юрисдикцію над будь-яким спором, а процедури досудового врегулювання спору стали непотрібними, навіть ті, які залишалися чинними, наприклад, комісії по трудових спорах. Таким чином, традиційний історичний підхід до подання спорів на розгляд судді у винятковому випадку, коли їх неможливо було вирішити за допомогою альтернативних способів, у тому числі засобами медіації, арбітражу чи із залученням третіх осіб, поступово зник. Однак альтернативне вирішення спорів частково повертається нині в межах судової реформи та реформування системи врегулювання спорів. Ця реформа ще далека від завершення, а може, ще навіть і не почалася. Новий підхід до врегулювання спорів, спрямований на відхід від принципу державної монополії на вирішення спорів, поки що не закріпився у свідомості правників, державних службовців, суддів, працівників правоохоронних органів чи політиків в Україні. У статті наголошується на важливості врахування під час змін ширшої європейської перспективи. Така перспектива стосується не лише теоретичних і практичних переваг недержавного врегулювання спорів, але й передбачає, що система недержавного та альтернативного вирішення спорів - це міжнародне зобов'язання в наднаціональному правовому порядку Європейського Союзу. Таке зобов'язання посідає чільне місце і в системі права Ради Свропи. Обидві системи мають широкий набір підходів, побудованих на рекомендаційних нормах м'якого права, на принципах права, які формуються судовою практикою Європейського суду з прав людини. Цей підхід передбачає, що альтернативні способи вирішення спорів, зокрема арбітраж, не суперечать принципам прав людини щодо справедливого судочинства. Навіть навпаки, вони стануть корисним інструментом вирішення конфліктів для будь-якого сучасного європейського суспільства, побудованого на принципах поваги до верховенства права.

Ключові слова: альтернативні способи вирішення спорів, доступ до правосуддя, право на справедливий суд, права людини, досудове врегулювання, вирішення конфліктів, медіація.

Manuscript submitted 29.05.2021

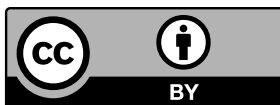

Creative Commons Attribution 4.0 International License (CC BY 4.0) 